O.P. RYZHOVA, PhD in Engineering

R.I. KYSLYCHNA, PhD in Engineering

T.I. NAHORNA, PhD in Engineering

S.YU. NAUMENKO, PhD in Engineering

\title{
GRAY NON-PIGMENT GLASS COATINGS
}

\begin{abstract}
Color is an important indicator of the aesthetic evaluation of the quality of materials and products for various purposes. The visual perception of the color by the human eye is subjective. For achromatic colors, the human eye responds better to a change in brightness (lightness) of dark colors than light ones, since the relative increment of lightness is higher in the first case than in the second. Gray is an achromatic color, which is the result of a mixture of classic colors - black and white. Depending on the lightness, the shade of gray changes from black (lightness 0\%) to white (lightness 100\%). In combination with other colors, it decorates any interior, emphasizes its dignity. Gray color is in great demand in the manufacture of steel enamelled household articles. To obtain a light gray color, the basic sodium borosilicate system $\left(\mathrm{Na}_{2} \mathrm{O}-\mathrm{B}_{2} \mathrm{O}_{3}-\mathrm{SiO}_{2}\right)$ was chosen. For the experimental enamels, physicochemical properties were determined, and for glass coatings - lightness and brilliance. In order to improve these properties, the components in the composition of enamels were varied. Leachability of the best enamel was $0.11 \mathrm{~cm}^{3} / \mathrm{g}$, temperature coefficient of linear expansion $-94.2 \cdot 10^{-7}$ degrees $^{-1}$, spreadability $-24.3 \mathrm{~mm}$, gloss of the glass layer $-76 \%$, lightness $-57 \%$, the coating withstood the effect of $4 \%$ th acetic acid for 5 minutes without losing gloss. On this enamel, the dependence of lightness and tint of the glass layer on the amount (0.067-0.6 parts by weight) of coloring oxides ( $\mathrm{CuO}, \mathrm{NiO}$, CoO), which were injected in excess of $100.0 \%$ by weight, was studied. The optimum content of the coloring components was determined. Non-pigmented glass coatings of light gray color with a delicate blue tint and lightness 60-70\% have been developed, which can be used for enameling kitchen and tableware, as well as for other types of steel articles for household use.
\end{abstract}

Keywords: gray color, glass enamel, enameled products, amount of coloring oxides, lightness.

\section{INTRODUCTION}

In the conditions of the modern consumer goods market, enterprises producing enameled products take into account the increasing requirements for products covered with silicate glass enamels.

In comparison with other coatings (organic and electroplating), glass enamel coatings are distinguished by high hygienic, long service life and high decorative characteristics.

To obtain competitive products, it is necessary to constantly expand the range of enamels, their color range and aesthetic and decorative characteristics while maintaining the required physicochemical and performance properties, including chemical and corrosion resistance to food environments and atmospheric influences. In addition, glass-enamel coatings should not contain toxic components that adversely affect human health $[1 ; 2]$.

Trends of modern design in the field of decorating enameled household articles (dishes, parts of electric and gas stoves, architectural panels, etc.) are aimed at obtaining coatings of achromatic colors. These colors provide an exquisite backdrop for using a wide range of decals. In contrast to white and black colors, it is light gray colors that make it possible to provide a person with a positive psycho-emotional state in everyday life.
For achromatic colors, lightness (the degree of dispersion, that is, the \% presence in a color of white and light gray tones) is the only characteristic. Black color has the minimum value of lightness (0\%), and white maximum (100\%) [3]. Gray glasses, called neutral or smoky, are characterized by uniform transmission throughout the visible spectrum [4]. Due to the lack of ready-to-use dye gray, with which you can get gray staining, it is necessary to apply a mixture of two or three coloring components. The combination of dyes is chosen so that the color caused by them is complementary to the base color of the coating, and the mixing of dyes is a subtractive process. With the help of the third dye correction is carried out so that the final color is as close as possible to the neutral one.

Gray glass enamels used for the manufacture of varietal utensils and other products using ceramic pigments are non-uniform. For dosing of dyes it is necessary to take into account the influence of the composition of the main glass. Ionic dyes can be present in glass in various degrees of oxidation, which depends primarily on the conditions of cooking and the interaction of two or more coloring ions simultaneously present in the glass. From the literature it is known the difficulty of predicting the resulting color of the glass layer when using several ionic dyes simultaneously. Good results in reproducibility of staining are primarily 
obtained using the following dye combinations: $\mathrm{Fe}_{2} \mathrm{O}_{3}-\mathrm{NiO}-\mathrm{CoO}$ and $\mathrm{Cr}_{2} \mathrm{O}_{3}-\mathrm{NiO}-\mathrm{CoO}[3 ; 4]$. From an environmental point of view, glass enamels that do not contain harmful components are more applicable. Therefore, it became necessary to obtain a gray enamel coating based on enamel fluoridefree enamel with the addition of the above oxides.

\section{AIM OF THE WORK}

To study the combined effect of coloring oxides $(\mathrm{CuO}, \mathrm{NiO}, \mathrm{CoO})$ in the quantities studied on the change in color of the glass layer and to select their optimum ratio. Get a coating of light gray with a blue tint with a given lightness of $60-70 \%$.

\section{METHODS OF RESEARCH AND THEIR RESULTS}

The composition of the enamel mixture according to the calculated recipe included the following materials: quartz sand, titanium dioxide, boric acid, alumina, chalk, sodium and potassium nitrate, sodium tripolyphosphate and iron scale. Coloring oxides were introduced for melting enamel in excess of 100.0 wt. \%.

Preparation of the charge for melting was carried out according to the generally accepted technology, i.e. dry, clean, prepared materials were crushed, sieved through a sieve No. 07 (98 holes/ $\mathrm{cm}^{2}$ ) and mixed well. The moisture content of the mixture was $3 \%$.

Experienced enamels melted at a temperature of $1260-1280{ }^{\circ} \mathrm{C}$ for $58-65$ minutes. Frits were obtained by the method of wet granulation, then dried and ground according to the following recipe, parts by weight: 100.0 frits; 5.0 chasovyarskaya clay; $0.1 \mathrm{NaNO}_{2}$ and $40.0 \mathrm{ml}$ of water. After 24 hours of aging, the enamel suspension was applied to primed steel samples, which, after drying at a temperature of $1100 \mathrm{C}$, were burned in the temperature range: $800-820-860{ }^{\circ} \mathrm{C}$. The quality of the glass layer was assessed visually by the degree of melting and perceived color, and the optical parameters were determined using the spectrocolorimeter "Pulsar".

The properties of the frits spreadability, water resistance, and temperature coefficient of linear expansion (TCLE) were determined by standard methods. The enamel is water resistant to the II-th hydrolytic class (leachability is $0.11 \mathrm{~cm}^{3} / \mathrm{g}$ ), TCLE $-94.2 \cdot 10^{-7}$ degrees- 1 , spreadability $-24.3 \mathrm{~mm}$. The coating is gray in color with a brown tint, the gloss of the glass layer is $76 \%$, the lightness index is $57 \%$. Glass coatings withstand the effect of $4 \%$ acetic acid for 5 minutes without losing gloss, which meets the requirements for coating enamel, which can be used for external application to household appliances $[5 ; 6]$.

\section{DISCUSSION OF RESEARCH RESULTS}

Obtaining a uniform gray color non-pigment glass-enamel coatings is a difficult task, which is caused by the problem of obtaining a slightly damped glass base and the selection of a certain amount of coloring oxides. Sodium borosilicate $\left(\mathrm{Na}_{2} \mathrm{O}-\mathrm{B}_{2} \mathrm{O}_{3}-\mathrm{SiO}_{2}\right)$ was chosen as the base system in which the following limits of the content of components were determined, wt.\%: 46.8-49.8 $\mathrm{SiO}_{2} ; 12.9-18.3 \mathrm{~B}_{2} \mathrm{O}_{3} ; 1.5-3.5 \mathrm{TiO}_{2} ; 3.0-4.5 \mathrm{Al}_{2} \mathrm{O}_{3}$; $2.1-9.0 \mathrm{CaO} ; 14.5-18.0 \mathrm{Na}_{2} \mathrm{O} ; 2.0-3.5 \mathrm{~K}_{2} \mathrm{O}$; 3.5$5.5 \mathrm{P}_{2} \mathrm{O}_{5} ; 0.5-1.5 \mathrm{Fe}_{2} \mathrm{O}_{3}$. After analyzing the physicochemical properties of enamels, the quality of the glass layer and the lightness index, the enamel composition containing the following components, was selected as the basis for producing light gray coatings. The selected enamel is characterized by weak silence due to a small amount of titanium dioxide. Therefore, the density of light gray color will be higher. A light gray color is obtained by combining the process of ionic staining and isolating the fine crystalline phase of $\mathrm{TiO}_{2}$.

It is possible to obtain a gray coating with a given lightness on the basis of the selected enamel, however, the glass layer is characterized by color heterogeneity. This is due to the presence of iron (III) in its composition. Paired combinations of coloring components, for example: copper and nickel oxides, result in coatings with a brown-green tint. The combination of oxides of cobalt and nickel helps to obtain blue-brown shades on the coating. Glass coatings with a salad blue shades can be obtained by applying the oxides of copper and cobalt. To eliminate the undesirable brown tint of the coating, compositions of copper, nickel, and cobalt oxides were used in the work.

According to modern concepts, the basic components of glass form an environment in which redox reactions take place between the elements of variable valence [7]. Such a medium, which is an alkaline silicate melt, consists mainly of silica and aluminoboric anions of varying degrees of complexity, cations of alkali and alkaline earth metals, as well as oxygen ions, among which are bridging (associated only with silicon cations), non-bridge and free $\mathrm{O}^{2-}$ ions. From the standpoint of the theory of acids and bases, it is the latter that have the greatest activity and are typical bases.

Important for the redox potential of glass melt is the basicity of the melt, as well as the presence of dye ions ( $\mathrm{CuO}, \mathrm{NiO}, \mathrm{CoO})$, which perform mainly the functions of modifiers, are located in the cavities of the structural network, dyes are in oxygen enamel dissolved form, and they are more or less solvated by enamel molecules. Enamels with such dyes are painted immediately during melting. The oxygen released by them during the melting process increases 
the internal oxygen pressure in the melt, delaying the dissociation of the coloring oxide. In the production of colored glasses and enamels, in most cases, staining with compositions of two or more coloring ions is used. The combinations of dyes ( $\mathrm{CuO}, \mathrm{NiO}$, $\mathrm{CoO}$ ) used by us in the studied ratios (fig. 1-3)

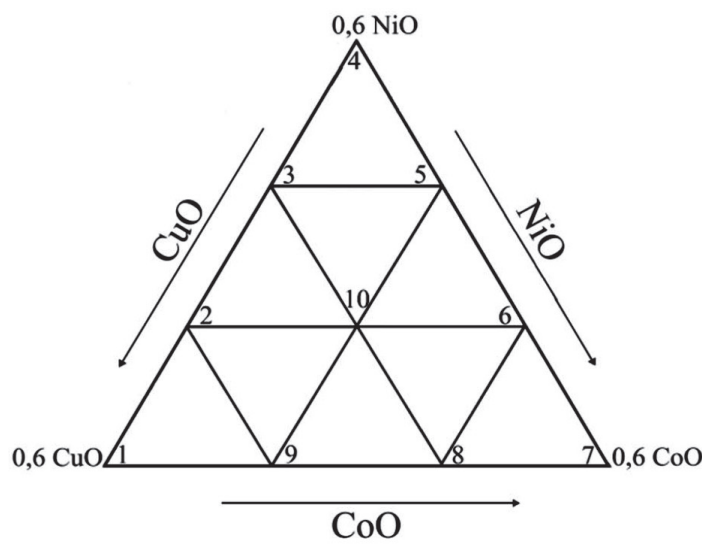

a)

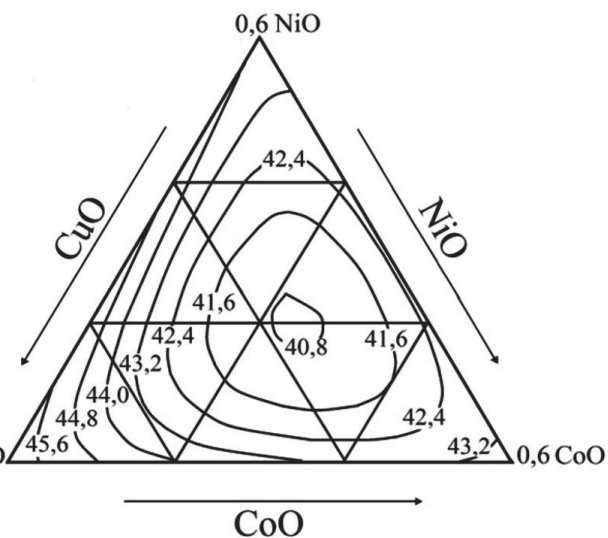

b)

Fig. 1. The amount of coloring oxides of 0.2-0.6 parts by weight (a) and the lightness of gray coatings, \% (b)

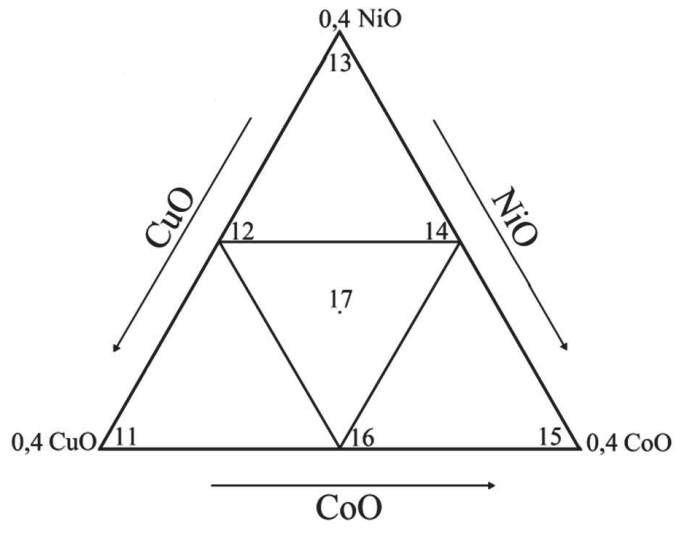

a)

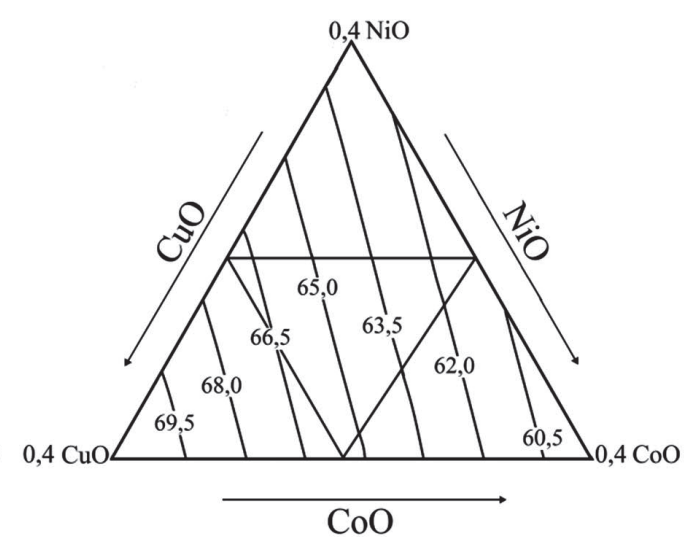

b)

Fig. 2. The amount of coloring oxides $0.13-0.4$ parts by weight (a) and the lightness of gray coatings, $\%$ (b)

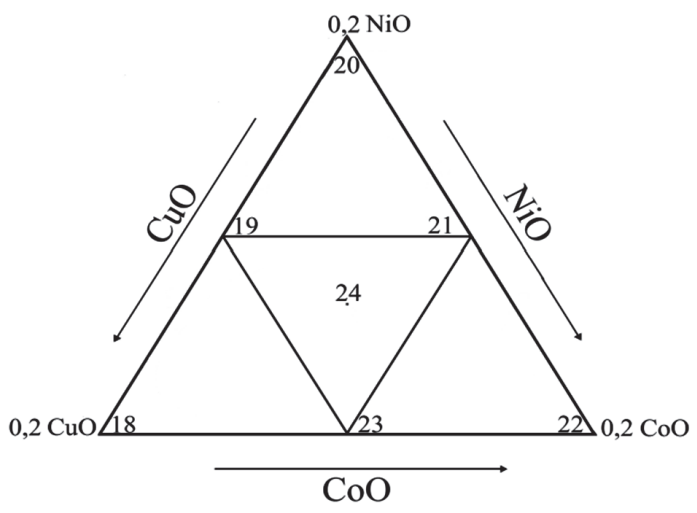

a)

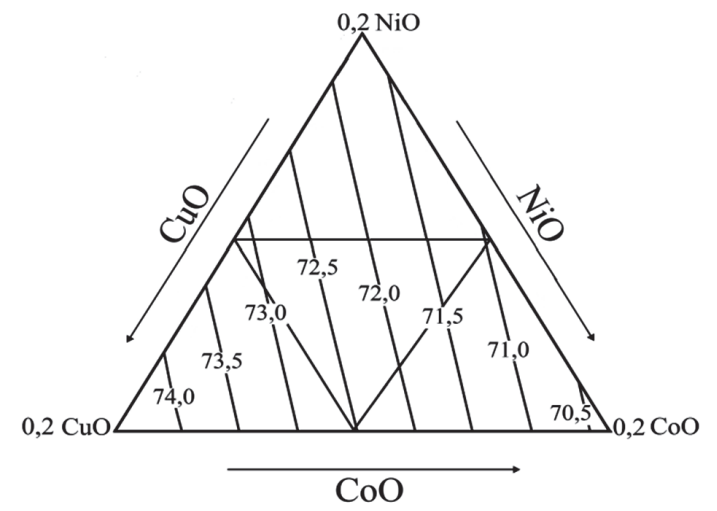

b)

Fig. 3. The amount of coloring oxides is 0.067-0.2 parts by weight (a) and lightness values of gray coatings, $\%$ (b) 
due to their individual color when mixed ensure the formation of a glass layer of gray color [3].

Dyeing metal oxides were introduced to the enamel melting, initially in the maximum amount of 0.6 parts by weight (fig. 1). The compositions with $\mathrm{CoO}$ had a gray color with a pronounced blue tint; with $\mathrm{CuO}$ - with a touch of salad; with $\mathrm{NiO}-$ brown tint. Special attention is attracted by glass coatings which include two or three coloring oxides. The following compositions were the best in terms of density, smoothness and neutrality of color, parts by weight: $\mathrm{N} 55-0.2 \mathrm{CoO}$ and $0.4 \mathrm{NiO}$; $\mathrm{N}^{\circ} 6-0.4 \mathrm{CoO}$ and $0.2 \mathrm{NiO}$; No10 - 0.2 CoO, $0.2 \mathrm{NiO}$ and $0.2 \mathrm{CuO}$. The lightness of the glass layer ranges from 40.8 to $45.6 \%$. At the same time, these coatings are not light gray in terms of lightness, but have a rich gray color. We also investigated other amounts of coloring oxides (0.13-0.4 parts by weight, fig. 2) and (0.067-0.2 parts by weight, fig. 3).

After analyzing the characteristics of enamel coatings, it was determined that the lightness index is directly proportional to the amount of coloring oxides in the enamel, i.e., as the dye content increases, the lightness index decreases. The presence in the enamel of the studied metal oxides of variable valence in the amount of $0.13-0.4$ parts by weight helps to obtain glass coatings with a lightness of $60.5-69.5 \%$, and $0.067-0.2$ parts by weight - with a lightness of enamel coatings $-70.5-74.0 \%$, which in terms of indicators approaches white coatings.

Based on the results of the research, we determined the optimal content of dyes, namely: 0.2 wt.h. $\mathrm{CoO}, \mathrm{CuO}$ and $\mathrm{NiO}$ (for coatings No12, $14)$, or the presence of all three dyes in the same amount ( 0.13 parts by weight) - coating No17.

\section{CONCLUSIONS}

As a result of the studies performed, the base enamel was selected to obtain gray glass coatings on its basis, the composition of ionic dyes ( $\mathrm{CuO}$, $\mathrm{NiO}, \mathrm{CoO}$ ) was selected over 100.0 wt.\%, Regularities of lightness change of non-pigmented glass enamel coatings of gray color were established.

Analysis of the lightness values of glass coatings showed that to obtain a light gray color of a glass layer with a blue tint and a lightness of 60$70 \%$, the following content of colored oxides is most preferable, parts by weight: $0.13-0.2 \mathrm{NiO}$; $\mathrm{CoO}$ and $\mathrm{CuO}$. The developed glass-enamel coatings are intended for external application to steel products for household purposes.

\section{REFERENCES}

1. Bragina, L.L., Zubehin, A.P., Belyy, Ya.I. at al. (2003). Tehnologiya emali i zaschitnyih pokryitiy
[Technology of enamel and protective coatings]. Harkov (in Russ.): NTU "HPI"; Novocherkassk: Yurgtu (NPI).

2. Shalygina, O.V., Pavelkova, V.A., Gavrylina, L.O. (2013). Zahysni bezpigmentni pokryttia sirogo koloru dlia poroshkovoi elektrostatychnoi tehnologii [Protective non-pigmented gray coatings for powder electrostatic technology]. Collection of scientific works. PAT "UkrNDlvognetriviv im. A.S. Berezhnogo", 113, 212-217.

3. Kotsik, I., Nebrzhenskiy, I., Fanderlik, I. (1983). Okrashivanie stekla [Glass coloring]. Moscow (in Russ.): Stroyizdat 1983.

4. Ilina, O.V., Bondareva, K.Yu. (2008). Tsvetovedenie $i$ koloristika [Color science and coloristics: studies]: tutorial. St. Petersburg (in Russ.).

5. Goleus, V.I. (2016). Osnovy himichnyh tehnologii skla, sklovyrobiv ta sklopokryttiv [Fundamentals of chemical technologies of glass, glassware and glass coverings]: tutorial. Dnipropetrovsk: litograf (in Ukr.).

6. Belyy, Ya.I., Ponomarchuk, S.M., Kislichnaya, R.I., Ryzhova, O.P. (1998). Legkoplavkaya stekloemal dlya okrashennyih besftoristyih pokryitiy [Lowmelting glassy metal for painted fluoride-free coatings]. Trudy ukrainskogo instituta stekla [Works of the Ukrainian Glass Institute]. Konstantinovka (in Ukr.), 229-233.

7. Petukhov, R.V., Tereshchenko, I.M., Kravchuk, A.P., Karpovich, E.V. (2010). Okislitelno-vosstanovitelnyiy potentsial steklomassy i tehnologicheskie protsessyi v proizvodstve listovogo stekla [Redox potential of glass and technological processes in the production of sheet glass]. Trudy BGTU [Works of the BSTU]. Seria III. Chemistry and technology of inorganic substances, XVIII, 80-82.

\section{СПИСОК ВИКОРИСТАНИХ ДЖЕРЕЛ}

1. Брагина Л.Л. Технология эмали и защитных покрытий / Л.Л. Брагина, А.П. Зубехин, Я.И. Белый и др. - Харьков: НТУ “ХПИ"; Новочеркасск: ЮРГТУ (НПИ) 2003. - 484 с.

2. Шалигіна О.В. Захисні безпігментні покриття сірого кольору для порошкових електростатичних технологій / О.В. Шалигіна, В.А. Павелкова, Л.О. Гавриліна // Збірник наукових праць. - ВАТ "УкрНДІвогнетривів імені А. С. Бережного". 2013. - № 113. - С. 212-217.

3. Коцик И. Окрашивание стекла / И. Коцик, И. Небрженский, И. Фандерлик. - Москва: Стройиздат, 1983. $-210 \mathrm{c}$.

4. Ильина О.В. Цветоведение и колористика : учеб. пособие / О.В. Ильина, К.Ю. Бондарева. Санкт-Петербург, 2008. - 120 с.

5. Голеус В.І. Основи хімічних технологій скла, скловиробів та склопокриттів : навч. посібник / В.І. Голеус. - Дніпропетровськ: Літограф, 2016. $-192 \mathrm{c}$.

6. Белый Я.И. Легкоплавкая стеклоэмаль для окрашенных бесфтористых покрытий / Я.И. Белый, С.М. Пономарчук, Р.И. Кисличная, О.П. Рыжова // Труды украинского института стекла. - Костантиновка, 1998. - 229-233.

7. Петухов Р.В. Окислительно-восстановительный потенциал стекломассы и технологические процессы в производстве листового стекла / Р.В. Петухов, И.М. Терещенко, А.П. Кравчук, Е.В. Карпович // Труды БГТУ; Серия III: Химия и технология неорганических веществ. - 2010. - Вып. XVIII. - C. 80-82. 
О.П. РИЖовА, канд. техн. наук, Р.І. КИсличнА, канд. техн. наук, Т.І. нАГОРНА, канд. техн. наук, С.ю. НАУМЕНКО, канд. Техн. наук

\section{БЕЗПІГМЕНТНІ СКЛОПОКРИТТЯ СІРОГО КОЛЬОРУ}

Резюме. Колір є важливим показником естетичної оцінки якості матеріалів і виробів різного призначення. Візуальне сприйняття кольору людським оком є суб'єктивним. Для ахроматичних кольорів людське око краще реагує на зміну яскравості (світлоти) темних кольорів, ніж світлих, оскільки відносне збільшення світла в першому випадку вище, ніж у другому. Сірий колір - це ахроматичний колір, який є результатом змішання класичних кольорів - чорного і білого. Залежно від світлоти відтінок сірого змінюється від чорного (світлота 0\%) до білого (світлота 100\%). У поєднанні з іншими кольорами він прикрашає будьякий інтер'єр, підкреслює його особливості. Сірий колір користується широким попитом при виготовленні сталевих емальованих виробів господарсько-побутового призначення. Для отримання світло-сірого кольору була обрана базова натрійборосилікатна система $\left(\mathrm{Na}_{2} \mathrm{O}-\mathrm{B}_{2} \mathrm{O}_{3}-\mathrm{SiO}_{2}\right)$. Для пробних емалей були визначені фізико-хімічні властивості, а для склопокриттів - світлота і блиск. 3 метою поліпшення цих властивостей проводилося варіювання компонентів у складі емалей. Вилуговування кращої емалі становило 0,11 см³/Г, температурний коефіцієнт лінійного розширення - 94,2·10-7 град ${ }^{1}$, розтікання 24,3 мм, блиск склослою - 76\%, показник світлоти - 57\%, покриття витримало дію 4\%-ї оцтової кислоти протягом 5 хвилин без втрати блиску. На цій емалі була вивчена залежність світлоти і відтінку склослою від кількості (0,067-0,6 мас.ч.) фарбувальних оксидів (CuO, NiO, CoO), які вводилися понад 100,0 мас.\%. Визначено оптимальний вміст фарбувальних компонентів. Розроблено безпігментні склопокриття світлосірого кольору з ніжним блакитним відтінком і світлотою 60-70\%, які можуть використовуватися для емалювання кухонного та столового посуду, а також для інших видів сталевих виробів господарськопобутового призначення.

Ключові слова: сірий колір, склоемаль, емальовані вироби, кількість забарвлюючих оксидів, світлота.

О.П. РЫЖОВА, канд. техн. наук, Р.И. КИслИЧнАЯ, канд. техн. наук, Т.И. НАГОРнАЯ, канд. техн. наук,

С.Ю. НАУМЕНКО, канд. техн. наук

\section{БЕСПИГМЕНТНЫЕ СТЕКЛОПОКРЫТИЯ СЕРОГО ЦВЕТА}

Резюме.Цвет является важным показателем эстетической оценки качества материалов и изделий различного назначения. Визуальное восприятие цвета человеческим глазом субъективно. Для ахроматических цветов человеческий глаз лучше реагирует на изменение яркости (светлоты) темных цветов, чем светлых, так как относительное увеличение светлоты в первом случае выше, чем во втором. Серый цвет - это ахроматический цвет, который является результатом смешения классических цветов - черного и белого. В зависимости от светлоты оттенок серого изменяется от чёрного (светлота 0\%) до белого (светлота 100\%). В сочетании с другими цветами он украшает любой интерьер, подчеркивает его достоинства. Серый цвет пользуется широким спросом при изготовлении стальных эмалированных изделий хозяйственно-бытового назначения. Для получения светло-серого цвета была выбрана базовая натрийборосиликатная система $\left(\mathrm{Na}_{2} \mathrm{O}-\mathrm{B}_{2} \mathrm{O}_{3}-\mathrm{SiO}_{2}\right)$. Для опытных эмалей были определены физико-химические свойства, а для стеклопокрытий - светлота и блеск. С целью улучшения этих свойств компоненты в составе эмалей варьировались. Выщелачиваемость лучшей эмали составила 0,11 см³/г, температурный коэффициент линейного расширения - 94,2:10-7град ${ }^{1}$, растекаемость - 24,3 мм, блеск стеклослоя - 76\%, показатель светлоты - 57\%, покрытие выдержало действие 4\%-й уксусной кислоты в течение 5 минут без потери блеска. На этой эмали была изучена зависимость светлоты и оттенка стеклослоя от количества (0,067-0,6 мас.4.) красящих оксидов (CuO, NiO, CoO), которые вводились сверх 100,0 мас.\%. Определено оптимальное содержание красящих компонентов. Разработаны беспигментные стеклопокрытия светло-серого цвета с нежным голубым оттенком и светлотой 60-70\%, которые могут использоваться для эмалирования кухонной и столовой посуды, а также для других видов стальных изделий хозяйственнобытового назначения.

Ключевые слова: серый цвет, стеклоэмаль, эмалированные изделия, количество красящих оксидов, светлота.

\section{INFORMATION ABOUT THE AUTHORS}

Ryzhova O.P. - PhD in Engineering, Associate Professor, vice-rector for scientific and pedagogical work of Ukrainian State University of Chemical Technology, 8, Haharin Ave., Dnipro, Ukraine, 49005; +38(056) 46-21-21; olgaryzhova2017@gmail.com

Kyslychna R.I. - PhD in Engineering, Researcher of Ukrainian State University of Chemical Technology, 8, Haharin Ave., Dnipro, Ukraine, 49005; +38(056) 47-38-96; Kislichnaya.ri@gmail.com

Nagorna T.I. - PhD in Engineering, Associate Professor of Ukrainian State University of Chemical Technology, 8, Haharin Ave., Dnipro, Ukraine, 49005; +38(056) 47-38-96; nagornaya.nti@ gmail.com

Naumenko S.Yu. - PhD in Engineering, Associate Professor of Ukrainian State University of Chemical Technology, 8, Haharin Ave., Dnipro, Ukraine, 49005; +38(056) 47-38-96; naymenko.su@gmail.com 


\section{ІНФОРМАЦІЯ ПРО АВТОРІВ}

Рижова Ольга Петрівна - канд. техн. наук, доцент, проректор з науково-педагогічної роботи дВнЗ "Український державний хіміко-технологічний університет", п-т Гагаріна, 8, м. Дніпро, Україна, $49005 ;+38$ (056) 46-21-21; olgaryzhova2017@gmail.com

Кислична Раїса Іванівна - канд. техн. наук, н. с. ДВНЗ “УДХТУ”, п-т Гагаріна, 8, м. Дніпро, Україна, 49005; +38 (056) 47-38-96; Kislichnaya.ri@gmail.com

Нагорна Тетяна Іванівна - канд. техн. наук, доцент ДВНЗ “УДХТУ”, п-т Гагаріна, 8, м. Дніпро, Україна, 49005; +38(056) 47-32-48; nagornaya.nti@ gmail.com

Науменко Світлана Юріївна - канд. техн. наук, доцент ДВНЗ “УДХТУ”, п-т Гагаріна, 8, м. Дніпро, Україна, 49005; +38 (056) 47-32-48; naymenko.su@gmail.com

\section{ИНФОРМАЦИЯ ОБ АВТОРАХ}

Рыжова О.П. - канд. техн. наук, доцент, проректор по научно-педагогической работе ГВуз "Украинский государственный химико-технологический университет”, п-т Гагарина, 8, г. Днепр, Украина, $49005 ;+38$ (056) 46-21-21; olgaryzhova2017@gmail.com

Кисличная Р.И. - канд. техн. наук, н. с. ДВНЗ “УГХТУ”, п-т Гагарина, 8, г. Днепр, Украина, $49005 ;+38$ (056) 47-38-96; Kislichnaya.ri@gmail.com

Нагорная Т.И. - канд. техн. наук, доцент ДВНЗ “УГХТУ”, п-т Гагарина, 8, г. Днепр, Украина, $49005 ;$ +38 (056) 47-32-48; nagornaya.nti @ gmail.com

Науменко С.ю. - канд. техн. наук, доцент ДВНЗ “УГХТу”, п-т Гагарина, 8, г. Днепр, Украина, $49005 ;$ +38 (056) 47-32-48; naymenko.su@gmail.com
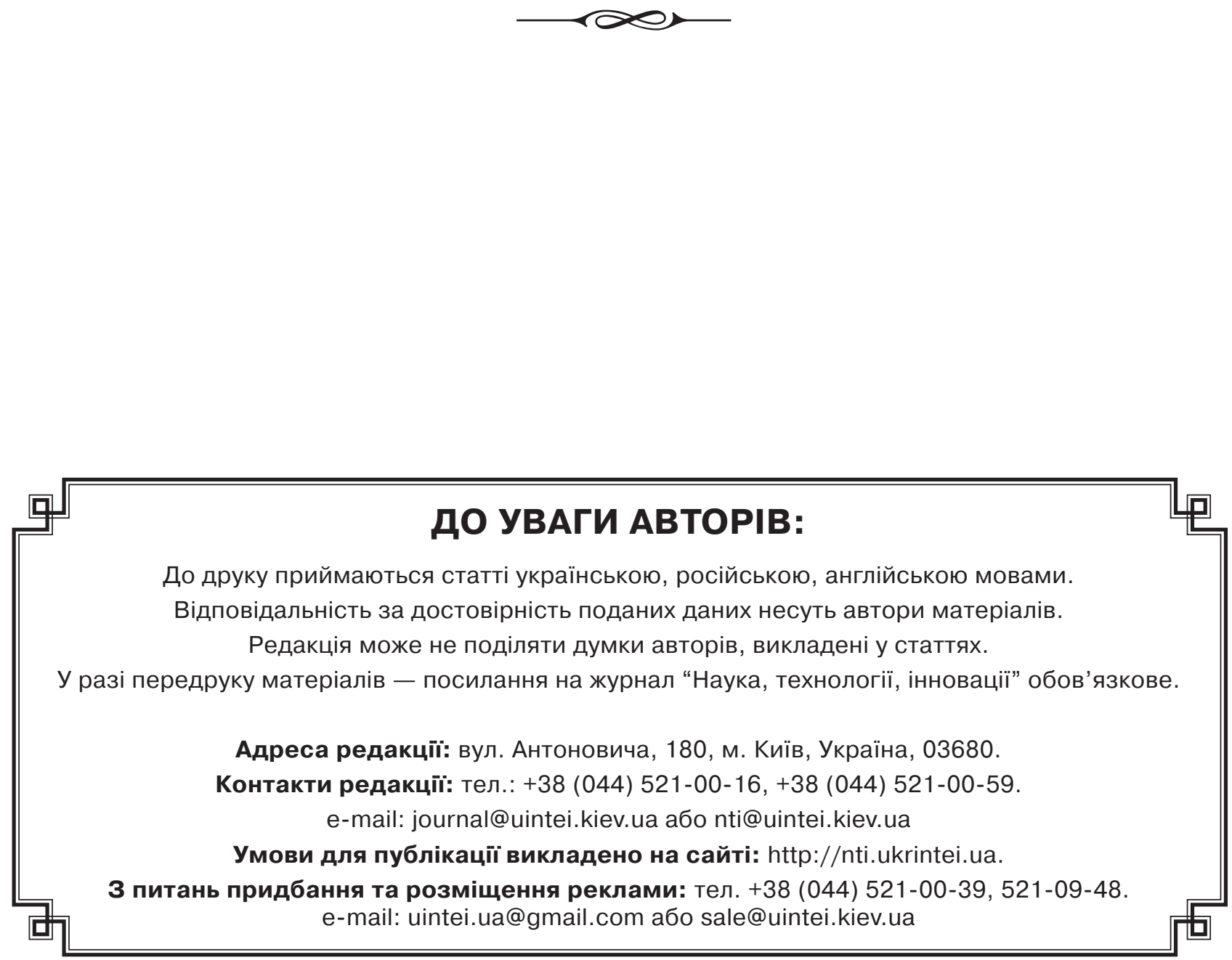